\title{
Charitable Endowment and Social Change: Cy-Près Orders and Schemes, 1837-1901
}

\author{
Charles Mitchell
}

Professor of Law, University College London

\begin{abstract}
The article discusses the law governing cy-près applications of charitable endowment during the Victorian period and the institutional framework within which cy-près orders and schemes were made. Powers to make such orders and schemes were vested in the Court of Chancery and the Charity Commissioners, a body of administrative officials created in 1853. Some case-studies are undertaken, to gain a better understanding of the approaches taken by the court and the Commissioners towards the making of orders and schemes and of their opinions regarding certain social, religious and political issues.
\end{abstract}

\section{Introduction}

In 1818 the Brougham Commissioners were appointed to investigate charitable trusts for educational purposes in England and Wales. ${ }^{1}$ Their remit was widened in 1819 and they went on to examine over 29,000 charitable trusts of every kind, and to publish 40 volumes of reports. Their task came to an end in 1837, the year of Victoria's accession to the throne. They reported that much property was being mismanaged or misapplied or applied to outdated purposes and they recommended that a new, permanent body of Charity Commissioners should be created to address these problems.

Legislation to this effect was passed in 1853, after a drawn-out battle between reformers and representatives of the Church of England and other charitable institutions opposed to outside interference with their activities. Under the compromise which was finally struck, many of these bodies, and their endowments, were exempted from the new Commissioners' jurisdiction. This was a disappointment to reformers, as was their failure to secure a consensus that the new Commissioners should not only be tasked with the investigation and correction of mismanagement and abuse but should also carry out a systematic redistribution of charitable endowment from existing charitable purposes into new purposes that would be more useful. The new Commissioners were given powers to redirect charitable trust funds that coincided with the powers invested in the Court of Chancery to apply charitable property cy-près, i.e. to apply the funds as nearly as possible to the original purposes of the trust, where these had become impossible or impracticable. They were also given limited powers to redirect some charitable funds into new purposes, whether or not the original trust purposes could still be performed. However, they were never authorised to do this in a comprehensive way.

The creation of the Charity Commissioners formed part of a general movement towards administrative reform led by Whig governments in the decades after 1832,

\footnotetext{
${ }^{1}$ B. Hargrove, 'The Reform of the Law and the Administration of Charities in the Nineteenth Century', PhD thesis, University of London, 1963, 17-280; R.S. Tompson, The Charity Commission and the Age of Reform, London, 1979.
} 
when the parliamentary franchise was extended by the First Reform Act. ${ }^{2}$ There are contradictory aspects to this story. On the one hand, the Whigs sought to eliminate sinecure offices, ${ }^{3}$ assumed a new and 'unprecedently wide-ranging' responsibility for domestic policy-making, restructured local government, ${ }^{4}$ and created, in the Poor Law Commission, 'a body exercising exceptionally wide and continuing powers over local authorities' ${ }^{5}$ This set a precedent for the creation of other state regulatory agencies, including the Charity Commissioners. On the other hand, while the Whigs supported the centralisation and rationalisation of government services, they also favoured economic retrenchment and opposed taxation; hence there was 'little expectation' in the 1830s and 1840s that the government 'should use a very significant proportion of national resources to attempt to ameliorate social injustice ...', for an expensive state was still 'associated with "extravagance" and the perpetuation of unfair privileges' ${ }^{6}$ As a result, the centralising impact of the new agencies was 'quite limited and, in some cases, largely overborne after a few years' unsatisfactory and antagonistic efforts to implement them', since they 'were often pitiably small and ineffective by comparison with the stated principle of centralised supervision with which they were launched'? As we shall see at various points in this article, the Charity Commissioners faced many challenges to their authority, some of which they won and some of which they lost. This remained a feature of their experience throughout the Victorian period.

The idea that the state should be kept small persisted throughout the nineteenth century, during the second half of which the dominant political ideology was liberal individualism, i.e. the idea that citizens should be afforded the freedom to realise their abilities and desires so far as this was compatible with the same wish in others. ${ }^{8}$ There was therefore a paradoxical aspect to Victorian state activity, for in the long run, 'centralisation, forged at a time when laissez-faire was the dominant ideology, would make many social reforms and a paternalistic state possible'. ${ }^{9}$ One shift in this direction was the emergence of government ministries in a modern form - in the 1830s, these

2 i.e. the Representation of the People Act 1832 ( 2 \& 3 Will IV., c. 45).

${ }^{3}$ P. Harling, The Waning of 'Old Corruption': The Politics of Economical Reform in Britain, 1779-1846, Oxford, 1996.

${ }^{4}$ Municipal Corporations Act 1835 (5 \& 6 Will. IV, c.171). This legislation is discussed further in the text to nn. 161-162.

${ }^{5}$ J. Innes, 'Central Government "Interference”: Changing Conceptions, Practices and Concerns, c. 1700-1850', in J. Harris, ed., Civil Society in British History: Ideas, Identities, Institutions, Oxford, 2003, 49.

${ }^{6}$ P. Harling and P. Mandler, 'From "Fiscal-Military" State to Laissez-Faire State, 1760-1850', 32 Journal of British Studies (1993) 44, 69.

${ }^{7}$ S. Devereaux, 'The Historiography of the English State During "the Long Eighteenth Century" 7 History Compass (2009) 742, 749.

${ }^{8}$ The political philosopher most often identified with this position is John Stuart Mill, whose On Liberty (1859) was strongly antipathetic to executive action (although more positive views are expressed in later writings. See generally e.g. M. Lobban, 'Theories of Law and Government' in W. Cornish et al, The Oxford History of the Laws of England: Volume XI: 1820-1914 English Legal System, Oxford, 2010, 94-100; S. den Otter, 'Individual and Social Responsibility in Nineteenth-Century British Political Thought', in M. Lobban and J. Moses, eds, The Impact of Ideas on Legal Development, Cambridge, 2012, 59-66.

${ }^{9}$ J. McLean, Searching for the State in British Legal Thought: Competing Conceptions of the Public Sphere, Cambridge, 2012, 32. 
were still small and 'ministers expected to attend to administrative detail' ${ }^{10}$ but in the 1840 s and 1850s it became settled that each of the main government departments should be headed by a member of Cabinet to whom executive powers were given by Parliament, who would answer to Parliament for the exercise of these powers, and who was given direction over and responsibility for a bureaucracy which would for the time being pursue his policies. ${ }^{11}$ In the 1860 s, new standards were set for poor relief, education, policing and public health, and in the 1870s and 1880s, compulsory spending requirements were imposed on local authorities, with the result that nearly all public investment was thereafter accounted for by their spending on 'infrastructure and social overhead: roads, waterworks, schools, town halls, tram lines, electricity stations, gasworks, work-houses'; these were typically paid for out of local taxes because central government 'was not willing to use general income taxes or indirect taxes to support or equalise the burden on local communities'.12

By the end of Victoria's reign, in 1901, the interest taken by central government ministries in the creation and implementation of domestic social policy had increased, and local government bodies had been reformed, by legislation which created county and borough councils, ${ }^{13}$ and then parish councils and urban and rural district councils. ${ }^{14}$ The latter bodies acquired the main secular functions of the old parish vestries: public health, burial grounds, urban lighting, public highways, etc.; the latter were assigned more important responsibilities for education and poor relief in the first decades of the twentieth century. ${ }^{15}$ State welfare spending and administration in this period were not comparable in scale and conception to what would follow in 1948. But it was already true by the turn of the century that the relative importance of charity and government to the 'mixed economy' of welfare provision had changed as a result of increased government activity in the late 1800 s, at central and, more importantly, at local levels. ${ }^{16}$

One result of all this was that the Charity Commissioners' work appeared less important by the end of the nineteenth century, and this may explain a change in the Commissioners' outlook which has been noted by historians. In David Owen's words,

${ }^{10}$ J.S. Anderson, 'Central Executive: The Legal Structure of State Institutions' in Cornish et al, Oxford History of the Laws of England, vol. XI, 345.

11 H. Parris, Constitutional Bureaucracy: The Development of British Central Administration Since the Eighteenth Century, London, 1969, 93-105 and ch. 5; N. Chester, The English Administrative System, 1780-1870, Oxford, 1981, 93-95.

${ }^{12}$ R. Millward and S. Sheard, 'The Urban Fiscal Problem, 1870-1914: Government Expenditure and Finance in England and Wales' 48 Economic History Review (2nd series) (1995), 501, 501.

${ }^{13}$ Local Government Act 1888 (51 \& 52 Vict., c. 41).

${ }^{14}$ Local Government Act 1894 (56 \& 57 Vict., c. 73).

${ }^{15}$ M Loughlin, 'Evolution and Gestalt of the State in the United Kingdom', in A. von Bogdandy, P.M. Huber and S. Cassese, eds., The Max Planck Handbooks in European Public Law: Volume I: The Administrative State, Oxford, 2017.

${ }^{16}$ For a sample of the literature on this topic, see G. Finlayson, 'A Moving Frontier: Voluntarism and the State in British Social Welfare, 1911-1949', 1 Twentieth-Century British History (1990), 183; J. Lewis, 'The Boundary between Voluntary and Statutory Social Service in the Late Nineteenth and Early Twentieth Centuries', 39 Historical Journal (1996), 155; B. Harris, The Origins of the British Welfare State: Society, State and Social Welfare in England and Wales, 1800-1945, Basingstoke, 2004; J. Stewart, 'The Mixed Economy of Welfare in Historical Context', in M. Powell, ed., Understanding the Mixed Economy of Welfare, 2nd edn, Bristol, 2019. 
after three or four decades of vigorous activity [the Commissioners' energy] palpably waned ... and in the years before 1914 (and after) their performance, as compared with their earlier initiative, seems unadventurous and routine. ${ }^{17}$

Nevertheless, the work done by the Charity Commissioners, and more particularly, the measures which they and (to a lesser extent) the courts took to redirect charitable funds from old into new purposes, played a significant part in the provision of welfare benefits during the nineteenth century. Studying their activities affords opportunities to examine the structure and context of Victorian administrative practices, by considering the legal rules by which the courts and Commissioners understood themselves to be bound and the opinions which they held about various social, political and religious issues.

These topics are examined here in the following way: sections II and III set out the legal and institutional framework within which cy-près orders and schemes were made, section IV undertakes some illustrative case studies, and section V concludes.

\section{The Chancery Court and its Cy-Près Jurisdiction}

\section{The Chancery Court}

The origins of the cy-près doctrine lie in the jurisdiction exercised by the ecclesiastical courts over testamentary charitable bequests. Applying rules of civilian and canon law, they would vary the terms of testamentary charitable trusts whose purposes could not be carried out. ${ }^{18}$ By 1800 , the Court of Chancery had taken jurisdiction over probate and executorships away from them, and with it their jurisdiction over charitable trustees and the power to order that charitable funds be applied cy-près. ${ }^{19} \mathrm{By}$ this time, however, the delays and expense to which Chancery litigants were exposed had become a national scandal, and this was one reason why reformers wished to move the oversight of charitable trusts to a new body of Charity Commissioners. ${ }^{20}$ This is considered below in section III, after the content of the judicial cy-près doctrine has been expounded.

${ }^{17}$ D. Owen, English Philanthropy 1660-1960, Cambridge, MA, 1964, 213. On the Commissioners' activities, see ibid., 182-208 and 247-308. And for similar assessments of their performance over time, see S.R. Mealing, 'The British Charity Commission and the Cy-Près Doctrine, 1853-94: A Study in the Decline of Reforming Zeal', 6 Histoire Sociale / Social History (1973), 5; M. Chesterman, Charities, Trusts and Social Welfare, London, 1979, 62-75; J.J. Fishman, 'Charitable Accountability and Reform in Nineteenth-Century England: The Case of the Charity Commission' 80 Chicago-Kent Law Review (2005), 724.

${ }^{18}$ G. Jones, History of the Law of Charity 1532-1827, Cambridge, 1969, 74; R.H. Helmholz, The Oxford History of the Laws of England, vol 1: The Canon Law and Ecclesiastical Jurisdiction from 597 to the 1640s, Oxford, 2004, 417-419.

${ }^{19}$ By the mid-1800s the county courts also exercised a cy-près jurisdiction over charitable trusts with an annual income of less than $£ 30$.

${ }^{20}$ e.g. Hansard, $2^{\text {nd }}$ series, vol. 38, cols 1221 (Henry Brougham) and 1230-31 (Sir Samuel Romilly) (3 June 1818); Hansard, $3^{\text {rd }}$ series, vol. 86, cols 806-7 (Lord Wrottesley) (18 May 1846); Hansard, $3^{\text {rd }}$ series, vol. 126, col. 1012 (Lord Cranworth LC) (3 May 1853); Hansard, $3^{\text {rd }}$ series, vol. 194, col. 1369 (WE Forster) (15 March 1869). 
An important preliminary point is that the cy-près doctrine applied only to charitable trusts, and the question whether a trust was charitable was understood to be a legal one, determined by reference to case law, and ultimately to the Preamble to the Statute of Charitable Uses $1601 .^{21}$ The key case in which Lord Eldon affirmed this proposition was Morice $v$ Bishop of Durham, ${ }^{22}$ decided at the start of the nineteenth century. Samuel Romilly, counsel for the plaintiffs, submitted in argument that there were

four objects, within one of which all charity, to be administered in this Court, must fall: 1st, relief of the indigent; in various ways: money: provisions: education: medical assistance; \&c.; 2dly, the advancement of learning; 3dly, the advancement of religion; and, 4thly, which is the most difficult, the advancement of objects of general public utility. ${ }^{23}$

Towards the end of the nineteenth century, this categorization of legally charitable purposes would come to be adopted by the House of Lords in Commissioner for Special Purposes of Income Tax v Pemsel. ${ }^{24}$ As Joshua Getzler has shown from a study of Lord Eldon's notebooks, ${ }^{25}$ however, the more immediate significance of Romilly's advocacy was that it confirmed Lord Eldon in the view that 'charity' was a legal term of art and that trusts for purposes were legally valid only if they fell within the law's definition of 'charitable purposes'. These were either purposes expressly listed in the 1601 Preamble or 'purposes having analogy to those'. ${ }^{26}$ Trusts for purposes that did not match this definition were void, even if their purposes aligned with some general idea of 'charity', as might have been said of 'benevolent purposes', for example.

Once a court had found a purpose to be legally charitable, its decision would bind future courts. Several aspects of this call for comment. First, if the question arose in a later case, whether the same purpose was legally charitable, the same answer would be given, even if the legal context in which the point arose differed from the context in which it had first been decided. So, for example, if a court held that the purposes of a testamentary trust of land were charitable, with the result that the trust was void under the mortmain statutes (unless formalities were complied with), ${ }^{27}$ a trust of personalty for the same purposes would be legally valid and enforceable as a charitable trust. ${ }^{28}$

${ }^{21} 43$ Eliz. 1, c. 4.

22 (1805) 10 Ves. Jun. 522, 32 ER 947. Earlier proceedings: (1804) 9 Ves. Jun. 399, 32 ER 656.

${ }^{23}$ (1805) 10 Ves. Jun. 522, 532; 32 ER 947, 951.

${ }^{24}$ [1891] AC 531, 583 (Lord Macnaghten).

25 J. Getzler, 'Morice v Bishop of Durham (1805)', in C. Mitchell and P. Mitchell, eds., Landmark Cases in Equity, Oxford, 2012, esp. 193, where Getzler quotes Lord Eldon's observation in his notebook that 'Charity has got a fixed Sense in the Court. Benevolence has not.'

${ }^{26}$ (1805) 10 Ves. Jun. 522, 541, 32 ER 947, 954.

27 i.e. the Charitable Uses Act 1736 (9 Geo. II, c. 36) and succeeding legislation. The law on mortmain was effectively (although not finally) abolished by the Mortmain and Charitable Uses Act 1891 (54 \& 55 Vict., c. 73).

${ }^{28}$ Compare Romilly MR's observations in Thornton v Howe (1862) 31 Beav. 14, 21; 54 ER 1042, 1044 (although these concerned the situation where a single purpose trust of mixed realty and personalty was created). 
Secondly, if the same question arose in a later case, the same answer would be given, even if contemporary opinion regarding the usefulness of the relevant purpose had changed in the meantime. So, for example, Chitty J held in Re Foveaux that

Dole charities were greatly in favour with our ancestors. Modern experience, regard being had to the increase of population, change of residence, and other altered circumstances, has shewn that such charities tend to pauperize a district, and are not beneficial; and in framing new schemes the court, having within the limits of judicial discretion to express its own views on the question, sets itself against this form of charity. Yet undeniably a dole charity if created at the present day is a valid charity. ${ }^{29}$

This does not mean that the courts could not develop the law of charity. They could, and did, recognize new charitable purposes by a process of analogical reasoning from the Preamble and from previous cases which had themselves recognized new charitable purposes by analogizing from the Preamble. ${ }^{30}$ During the Victorian period the courts also began to develop a new rule that the carrying out of a charitable purpose must enure to the 'public benefit', and to use this rule to deny charitable status to trusts for purposes that had previously been declared charitable. ${ }^{31}$ However, it was not until the twentieth century that the courts drew a clear distinction between charitable purposes and charitable status, 'the former being merely one (albeit necessary) element of the latter together with the requirement that the purpose be carried on for the benefit of a sufficient section of the community, ${ }^{32}$

Thirdly, once a charitable trust had been validly created, the trust funds had to be applied to the trust's purposes for as long as this was practically possible. They could not be applied to another purpose, no matter how desirable this might have seemed to the trustees or the court. So, in Philpott v St George's Hospital, Romilly MR said that

If the testator has, by his will, pointed out clearly what he intends to be done, and his directions are not contrary to the law, this court is bound to carry that intention into effect, and has no right and is not at liberty to speculate upon whether it would have been more expedient or beneficial for the community that a different mode of application of the funds in charity should have occurred to the mind of the testator ... Accordingly, instances of charities of the most

\footnotetext{
${ }^{29}$ [1895] 2 Ch. 501, 505. As discussed below, in the text to n. 34, a different approach was later taken National Anti-Vivisection Society v IRC [1948] AC 31. Doles were gifts of money, food or clothing.

30 e.g. Att.-Gen. v Heelis (1824) 2 Sim. \& St. 67, 77; 57 ER 270, 274 (Bolton town improvements); Trustees of the British Museum v White (1826) 2 Sim. \& St. 594, 57 ER 473 (British Museum); University of London v Yarrow (1856) 23 Beav. 159, 53 ER 63 (study of animal diseases); Beaumont v Oliveira (1869) LR 4 Ch. App. 309 (Royal Geographical Society).

31 e.g. Cocks v Manners (1871) LR 12 Eq. 574, 585; Yeap Cheah Neo v Ong Cheng Neo (1875) LR 6 PC 381, 396; Re White [1893] 2 Ch. 41, 53. Discussion in P. Ridge, 'Legal Neutrality, Public Benefit and Religious Charitable Purposes: Making Sense of Thornton v Howe' 31 Journal of Legal History (2010) 177, 199-202.

32 J. Garton, Public Benefit in Charity Law: Principles and Practice, Oxford, 2013, para. 1.22, identifying Oppenheim v Tobacco Securities Trust Co Ltd [1951] AC 297 as the case in which this step was decisively taken.
} 
useless description have come before the court, but which it has considered itself bound to carry into effect. ${ }^{33}$

Fourthly, a charitable purpose did not cease to be charitable because social circumstances had changed since the time when the trust had first been created. This rule was subsequently abrogated in 1948, in National Anti-Vivisection Society $v$ IRC. ${ }^{34}$ In that case, Lord Simonds purported to draw support from nineteenth-century cases concerning the cy-près application of surplus charitable funds, where the courts had declined to apply the surplus to purposes closely resembling those named by the settlor, on the ground that 'men's ideas have changed'. ${ }^{35}$ As Lord Porter said in his dissenting speech, however, it was one thing to hold that trust funds could be more usefully spent on a new purpose when a trust's original purpose had failed, and another to hold that a purpose had ceased to be legally charitable because social attitudes had changed. ${ }^{36}$ Victorian judges often made findings of the former type, but they did not consider that findings of the latter type were open to them, as Chitty $J$ and Romilly MR both made clear in the comments which have already been quoted.

\section{The Equitable Cy-Près Doctrine}

Following a period of judicial activism led by Arden MR and Lord Eldon in the late 1700 s and early $1800 \mathrm{~s},{ }^{37}$ the equitable rules governing the cy-près doctrine became settled and did not significantly change for the remainder of the nineteenth century. ${ }^{38}$ Indeed, the content of the equitable cy-près doctrine is substantially unchanged today, ${ }^{39}$

33 (1859) 27 Beav. 107, 111-112; 54 ER 42, 44. See too Att.-Gen. v Whitchurch (1796) 3 Ves. Jun. 141, 144; 30 ER 937, 939; Bishop of Hereford $v$ Adams (1805) 7 Ves. Jun. 324, 329; 32 ER 132, 134; Att.-Gen. v Earl of Mansfield (1827) 2 Russ. 501, 520; 38 ER 423, 430; Att.-Gen. v Calvert (1857) 23 Beav. 248, 254-5; 53 ER 97, 100; Commissioners for Special Purposes of the Income Tax v Pemsel [1891] AC 572, 572573.

${ }^{34}$ [1948] AC 31, departing from the earlier decision in Re Foveaux [1895] 2 Ch. 501, when holding that anti-vivisection had ceased to be a charitable purpose.

${ }^{35}$ Ibid., 67-70, quoting from Re Campden Charities (1881) 18 Ch. D. 310, 324 (Jessel MR) and also considering Att.-Gen. v Marchant (1866) LR 3 Eq. 424. The former case is discussed further below, in the text following nn. 57 and 142.

${ }^{36}$ Ibid., 57-8.

${ }^{37}$ See H. Gray, 'The History and Development in England of the Cy-Près Principle in Charities' 33 Boston University Law Review (1953), 30; Jones, History of the Law of Charity, 138-156; J. Picton, 'Moggridge v Thackwell: Defining the Nature of the Courts' Scheme-Making Power' 15 Charity Law \& Practice Review (2013), 59.

38 This assessment is based on a reading of nineteenth-century cases and the following works: W.F. Finlason, A Brief and Practical Exposition of the Law of Charitable Trusts, London, 1860; O.D. Tudor, The Law of Charitable Trusts, 2nd edn, London, 1871; F.M. Whiteford, The Law Relating to Charities, London, 1878; L.S. Bristow and W.I. Cook, The Law of Charities and Mortmain, Being a Third Edition of Tudor's Charitable Trusts, London, 1889; L.S. Bristow, C.A. Hunt and H.G. Burdett, The Law of Charities and Mortmain, Being the Fourth Edition of Tudor's Charitable Trusts, London, 1906.

${ }^{39}$ For the current law, see W Henderson and J Fowles, Tudor on Charities, 10th edn, London, 2015, ch. 11. 
although the rules determining when the doctrine can be applied have been somewhat relaxed by legislation over the past fifty years.

The law distinguished between judicial and prerogative cy-près powers. ${ }^{40}$ The judicial cy-près doctrine applied where property was settled on a trust for charitable purposes which could not be carried out in the manner stated by the settlor; the prerogative cy-près doctrine applied where legal title to property was given to a charitable body without a declaration of trust, and where the property could not be applied in the manner stated by the donor. The judicial doctrine enabled the courts to make a scheme for application of the trust property; the prerogative doctrine enabled the Crown to apply the property cy-près by exercise of the sign manual. In either case, the trustees or donee could only apply the property to a new purpose under directions: they could not take it on themselves to do this. ${ }^{41}$

The judicial cy-près doctrine was the more significant of the two. This took in two classes of case: cases where a trust's purposes failed and cases where the terms of a trust were ambiguously expressed. Where there was ambiguity, the trust was not invalidated for uncertainty of objects (as a private trust would have been) and the courts would make a scheme directing the trustees how to apply the property. ${ }^{42}$ In such cases, the courts did not purport to alter the purposes to which the trust funds would be applied; they merely sought to construe the relevant trust documents to determine what these purposes were. However, cases of this kind were thought to be sufficiently similar to cases where a trust's purposes were clear, but impossible or impracticable, for the two types of case to be treated as different aspects of a single doctrine. ${ }^{43}$

In cases where a trust's purposes failed, a distinction was drawn between initial and supervening failure. Where a trust immediately failed, the trust funds could be applied cy-près only if the settlor had had a general charitable intention when declaring the trust. ${ }^{44}$ Where a testamentary gift was made to a named institution that had ceased to exist by the time of the testator's death, the courts were slow to find such a general intention, ${ }^{45}$ but they were quicker to do so where a legacy was made to an ostensibly charitable institution that had never existed. ${ }^{46}$ They would also discover a general charitable intention where the trust immediately failed for illegality, a rule that was said by Lord Eldon to be unjustifiable in principle, but too well entrenched to depart from. ${ }^{47}$ Where a trust was validly created, and its objects later failed, the funds were applied

\footnotetext{
${ }^{40}$ Moggridge v Thackwell (1803) 7 Ves. Jun. 36, 86; 32 ER 15, 32; Paice v Archbishop of Canterbury (1807) 14 Ves. Jun. 364, 372; 33 ER 560, 563; Ommanney v Butcher (1823) T. \& R. 260, 270; 37 ER 1098, 1101.

${ }^{41}$ Re Campden Charities (1881) 18 Ch. D. 310, 328-9.

${ }^{42}$ As in e.g. Mills v Farmer (1815) 19 Ves. Jun. 483, 34 ER 595 ('other charitable purposes as I do intend to name hereafter'; none named); Re Sutton (1885) $28 \mathrm{Ch}$. D. 464 ('charitable and deserving objects').

${ }^{43}$ Bristow and Cook, Third Edition of Tudor's Charitable Trusts, 139.

${ }^{44}$ Att.-Gen. v Boultbee (1794) 2 Ves. Jun. 380, 387-8; 30 ER 683, 687; Mayor of Lyons v Advocate-General of Bengal (1876) 1 App. Cas. 91, 112-4; Biscoe v Jackson (1887) 35 Ch. D. 460.

${ }^{45}$ Clark v Taylor (1853) 1 Drew. 642, 61 ER 596; Re Rymer [1895] 1 Ch 19.

${ }^{46}$ Bennett v Hayter (1839) 2 Beav. 81, 48 ER 1110; Re Maguire (1870) LR 9 Eq. 632.

${ }^{47}$ Moggridge v Thackwell (1803) 7 Ves. Jun. 36, 75-6 and 81; 32 ER 15, 28 and 30; Att.-Gen. v Mayor of Bristol (1820) 2 J. \& W. 294, 308; 37 ER 640, 645.
} 
cy-près regardless of whether the settlor had had any general charitable intention, ${ }^{48}$ unless the settlor had specified that in this case the property should result to his estate. ${ }^{49}$

The application of property to a trust's purposes was held to be impossible or impracticable in various situations, including: where the purposes were illegal, ${ }^{50}$ where the intended trustee refused the trusteeship $;{ }^{51}$ where the purposes required the purchase of property or appointment of an officer and none could be found; ${ }^{52}$ where changed circumstances made the purposes redundant; ${ }^{.3}$ and where the trust income had become greater than the expenditure needed to achieve the purposes. ${ }^{54}$ However, the courts would not sanction the application of increased funds to new purposes where increased expenditure on a trust's original purposes was still practicable. ${ }^{55}$

Some inroads were made into this last principle in Clephane v Lord Provost of Edinburgh ${ }^{56}$ and Re Campden Charities. ${ }^{57}$ In the former case, money was paid to compensate a charity for the destruction of its hospital building, and the House of Lords held that the money could be applied to outdoor poor relief rather than a new building. Lord Westbury justified this finding on the basis that there was a difference between the settlor's objective and the means directed for its accomplishment, and 'the means for the attainment of the end may be altered from time to time' ${ }^{58}$ In the latter case, funds for the purchase of apprenticeships and the giving of doles were applied to educational purposes and other modes of poor relief, according to Jessel MR because the court could make a cy-près order where a trust's purposes were out of line with 'the existing usages of society'. ${ }^{59}$ The Charity Commissioners claimed that these two cases

${ }^{48}$ Att.-Gen. v Earl of Craven (1856) 21 Beav. 292, 52 ER 910; Re Slevin [1891] 2 Ch. 236.

${ }^{49}$ Re Randell (1888) 38 Ch. D. 213, following Walsh v Secretary of State for India (1863) 10 HLC 367, 11 ER 1068.

${ }^{50}$ Att.-Gen. v Vint (1850) 3 De G. \& Sm. 704, 64 ER 669 (supply of porter to workhouse inmates); Habershon v Vardon (1851) 4 De G. \& Sm. 467, 64 ER 916 (restoration of Jews to Jerusalem would promote revolution against Ottoman empire); Thrupp v Collett (1858) 26 Beav. 125, 53 ER 844 (payment of fines imposed on poachers).

${ }^{51}$ Reeve v Att.-Gen. (1843) 3 Hare 191, 67 ER 351; New v Bonaker (1867) LR 4 Eq. 655.

${ }^{52}$ Biscoe v Jackson (1887) LR 35 Ch. D. 460; Att.-Gen. v Stewart (1872) LR 14 Eq. 17. ${ }^{53}$ Att.-Gen. v Mayor of City of London (1790) 3 Bro. CC 171, 29 ER 472 (propagation of Christianity among 'infidels' of Virginia; none remained); Att.-Gen. v Ironmongers' Co. (1834) 2 M. \& K. 576, 39 ER 1064 (release of Christian prisoners in Turkey or Barbary; none remained); Att.-Gen. v Earl of Craven (1856) 21 Beav. 392, 52 ER 910 (medical treatment and burial of plague victims; plague eliminated in the British Isles); Re Prison Charities (1873) LR 16 Eq. 129 (release of imprisoned debtors; imprisonment for debt abolished).

${ }^{54}$ As in e.g. Att.-Gen. v Haberdashers' Co. (1792) 4 Bro. CC 103, 29 ER 800; Mercers Co. v Att.-Gen. (1828) 2 Bli. NS 165, 4 ER 1094; Att.-Gen. v Rochester Corp. (1854) 5 De G. M. \& G. 797, 43 ER 1079; Re Campden Charities (1881) 18 Ch. D. 310.

${ }^{55}$ Att.-Gen. v Boultbee (1794) 2 Ves. Jun. 380, 387-8; 30 ER 683, 687; Att.-Gen. v Rochester Corp. (1854) 5 De G. M. \& G. 797, 813; 43 ER 1079, 1086; Re Palatine Estate Charity (1889) 39 Ch. D. 54, 58.

${ }^{56}$ (1869) LR 1 HL Sc. 417 (where English and Scots law were taken to be the same).

${ }^{57}$ (1881) 18 Ch. D. 310; discussed in greater detail in the text following n. 142.

${ }^{58}$ Clephane v Lord Provost of Edinburgh (1869) LR 1 HL Sc. 417, 421.

${ }^{59}$ Re Campden Charities (1881) 18 Ch. D. 310, 326. 
imparted a new elasticity to the law, ${ }^{60}$ but there was an element of wishful thinking in this. ${ }^{61}$ Jessel MR may have gone further than previous courts, but he ordered that part of the apprenticeship fund had to be used for its original purpose, and although he acted more freely towards the dole fund, the trustees had already stopped paying doles. ${ }^{62}$ There was no move by later courts to use Campden Charities to elaborate a new rule that funds could be applied cy-près whenever the court thought that another purpose would be more beneficial, and in 1910, in Re Weir Hospital, Cozens-Hardy MR reasserted earlier orthodoxy that 'there can be no question of cy-près until it is clearly established that the directions of the testator cannot be carried into effect.' 63

Once the cy-près doctrine had been triggered, a new purpose had to be identified which was 'as near as possible' to the purpose specified by the settlor. It was often said that the new purpose had to be the practicable purpose that was the closest to the purpose selected by the settlor, and that the views of the court as to the best possible use of the property were irrelevant, as was the fact that the settlor might have chosen a different purpose, had he foreseen the social changes which had taken place since the trust was settled. ${ }^{64}$ However, it was also said that social usefulness was a factor that could be taken into account along with proximity to the settlor's original purpose. ${ }^{65}$ As a result, the cases on this issue were inconsistent. Sometimes schemes were rejected because they were too far from the settlor's original purpose, as in Re Prison Charities, ${ }^{66}$ for example, where a gift for poor prisoners could not be used to fund a school for prisoners' children. Yet in other cases schemes were made that reflected the courts' own views more closely than those of the settlor; these are exemplified by Attorney-General v Ironmongers' Company, ${ }^{67}$ where a gift to redeem English sailors

${ }^{60}$ Twenty-eighth Report of the Charity Commissioners for England and Wales PP 1881 (HC No. 2862) 9-10.

${ }^{61}$ As noted in Hargrove, 'Charities in the Nineteenth Century', 352-354. As discussed in section III, the Commissioners had the same cy-près powers as the courts, and they wanted wider powers; hence they had an interest in characterising the scope of the court's powers as widely as they could.

${ }^{62}$ As noted in Report from the Select Committee on Charitable Trusts Acts PP 1884 (HC No. 306) 104-5 (QQ 1458-65, F. Vaughan Hawkins). See too Report from the Select Committee on Charity Commission PP 1894 (HC No. 221) 27 and 30 (QQ 391 and 444, Sir Henry Longley).

${ }^{63}$ [1910] 2 Ch. 124, 131. The Court of Appeal in Re Weir Hospital inaccurately characterized Campden Charities as a case where it had become impossible to carry out the settlor's purposes: ibid. 132 and 141.

${ }^{64}$ Att.-Gen. v Coopers' Co. (1812) 19 Ves. Jun. 187, 189; 34 ER 488, 489; Att.-Gen. v Boucherett (1858) 25 Beav. 116, 118-9; 53 ER 580, 581-2; Re Prison Charities (1873) LR 16 Eq. 129, 149.

${ }^{65}$ Att.-Gen. v Ironmongers' Co. (1844) 10 Cl. \& F. 908, 922; Re Campden Charities (1881) 18 Ch. D. 310; Re Weir Hospital [1910] 2 Ch. 124, 132.

${ }^{66}$ (1873) LR 16 Eq. 129. See too Att.-Gen. v Whiteley (1805) 11 Ves. Jun. 241, 32 ER 1080 (gift for 'grammar school education' could not be used to fund tuition in languages other than Latin and Greek); Att.-Gen. v Wansay (1808) 15 Ves. Jun. 231, 33 ER 742 (fund to buy apprenticeships for poor Presbyterian boys could not be used to benefit poor boys of other religions).

${ }^{67}$ (1844) $10 \mathrm{Cl}$. \& F. 908, 8 ER 983. Money from this trust was applied to educational purposes in 700 parishes: Report from the Select Committee on Charitable Trusts Acts 
captured by Barbary pirates was applied to educational purposes, despite Lord Campbell's pithy observation that 'if education in England be next to redemption of slaves in Barbary, it is next at a great interval'. ${ }^{68}$

\section{The Charity Commissioners and their Scheme-Making Powers}

\section{The Charitable Trusts Act 1853}

The Brougham Commissioners' recommendation in 1837, that a new, permanent body of Charity Commissioners be appointed, was not implemented quickly. Legislation to this effect was resisted by powerful institutions, including the Church of England, the universities, the London medical hospitals, and the City livery companies, all of which opposed outside control, ${ }^{69}$ and by the courts, which were loath to surrender their powers. Many commissions and select committees were convened, and thirteen bills were lost, before the Charitable Trusts Act 1853 was finally enacted. ${ }^{70}$

This authorized the appointment of three full-time paid commissioners, one part-time unpaid commissioner (who sat in the House of Commons and represented the Charity Commissioners' interests there) and a supporting staff. Their duties included the scrutiny of charity accounts, the investigation of suspected maladministration, the custodianship of charity property voluntarily transferred to them by trustees, the provision of advice to trustees on administrative matters, and the making of schemes for the application of charity property. The Charity Commissioners were responsible only for charitable endowments, i.e. property held for charitable purposes where the capital could not be spent. ${ }^{71}$ This meant that they had oversight of charitable trusts and some charitable corporations, but not of bodies which operated as 'collecting charities' and could spend their funds without observing any distinction between capital and income. Charities with visitors or other supervisory officers were also exempted from the Commissioners' jurisdiction, e.g. cathedrals, universities, and some schools unfortunately, said critics, given that the Brougham Commissioners had found 'many of the worst cases of abuse and maladministration ... in charities having special visitors ... [particularly] the minor Grammar Schools'. ${ }^{72}$

Many Charity Commissioners were lawyers whose training and professional habits led them to take a distinctly legal, not to say legalistic, approach to problems of charity administration. ${ }^{73}$ Peter Erle, the first Chief Commissioner, was a conveyancer, and brother to Sir William Erle, Chief Justice of Common Pleas. James Hill, another early Commissioner, was a barrister and the author of a textbook on trusts law. ${ }^{74}$ Arthur

PP 1884 (HC No. 306) 23 (Q 311, Henry Longley). See too Re Ashton's Charity (1859) 27 Beav. 115, 54 ER 45 (gift for almswomen used to fund a school).

${ }^{68}$ Ibid, 10 Cl. \& F. 925.

69 And continued to do so whenever an extension of the Charity Commissioners' powers was mooted: e.g. Report from the Select Committee on Charitable Trusts Acts PP 1884 (HC No. 306) 234 (QQ 3673-5, Douglas Richmond).

${ }^{70}$ J.P. Fearon, The Endowed Charities: With Some Suggestions for Further Legislation Regarding Them, London, 1855, 24-46.

${ }^{71}$ Charitable Trusts Act 1853 (16 \& 17 Vict., c.137), ss 62 and 66.

${ }^{72}$ Fearon, Endowed Charities, 12. Efforts were made to remedy some of these problems by the enactment of the Endowed Schools Acts 1869; see sub-section (3) below.

${ }^{73}$ Owen, English Philanthropy, 203.

${ }^{74}$ J. Hill, A Practical Treatise on the Law Relating to Trustees, London, 1845. 
(later Sir Arthur, later Lord) Hobhouse was a Chancery barrister from 1845 to 1866. Illness caused him to leave the Bar and become a Charity Commissioner; after working as an Endowed Schools Commissioner he later succeeded Sir James Fitzjames Stephen as law member of the council of the viceroy of India in 1872 and became a member of the Judicial Committee of the Privy Council in 1881. Henry (afterwards Sir Henry) Longley, eldest son of the Archbishop of Canterbury, was called to the Bar in 1860, was a Poor Law inspector and Local Government Board inspector in the 1870s and a Charity Commissioner and later Chief Charity Commissioner in the 1880s and 1890s.

Prior to the passing of the 1853 legislation, reformers had hoped that the new Charity Commissioners would be empowered to modernize all charitable endowment, by reallocating funds held for purposes that had ceased to be socially beneficial. The 1853 bill contained a clause that would have empowered the Commissioners to transfer any charitable funds to any charitable objects in four cases: failure of the trust's original purpose, departure from the founder's intention or the creation of pauperism or immorality, where the union of charities would create efficiencies, and where a trust of more than 60 years standing had no or little or beneficial effect. ${ }^{75}$ This would have given the Commissioners powers that went well beyond the courts' cy-près jurisdiction, but the clause was cut down in committee. The Commissioners never subsequently acquired such general powers, although they sought them for many years, ${ }^{76}$ and they did acquire powers to apply some types of charity property to new purposes in circumstances that went beyond the scope of the cy-près doctrine, under the Endowed Schools Act 1869 and the City of London Parochial Charities Act $1883 .{ }^{77}$ In 1881 and 1882 , bills were lost that would have widened their general powers, and no action was taken to implement the subsequent recommendations of Select Committees in 1884 and 1894 that these general powers should be enlarged. ${ }^{78}$

The 1853 Act gave the Charity Commissioners no power to alter trust purposes on their own initiative, nor to make or amend schemes for the cy-près application of charitable funds. Where they thought that a cy-près application would be desirable, they had to certify the case to the Attorney-General, who would hold an inquiry and where appropriate bring Chancery proceedings for the establishment of a scheme. ${ }^{79}$ Where the Commissioners wished to effect a more substantial reorganisation of a charity's affairs they had to present their scheme to Parliament as a private bill. Neither mechanism was satisfactory. Proceedings in Chancery were slow and expensive, and because no Minister was responsible for steering the Commissioners' schemes through Parliament,

${ }^{75}$ Hansard, $3^{\text {rd }}$ series, vol. 126, cols. 1016-1017 (Lord Cranworth LC) (3 May 1853).

${ }^{76}$ A recurring theme in their Reports: e.g. Sixth Report of the Charity Commissioners for England and Wales PP 1859 (HC No. 2484) 5; Seventeenth Report of the Charity Commissioners for England and Wales PP 1870 (HC No. 73) 5; Twenty-eighth Report of the Charity Commissioners for England and Wales PP 1881 (HC No. 2862) 10-12.

${ }^{77}$ Discussed in sub-sections 3 and 4 below. The Prison Charities Act 1882 (45 \& 46 Vict., c. 65) also authorized the application of funds for the benefit of imprisoned debtors to new purposes, a power used to benefit discharged prisoners: Thirty-sixth Report of the Charity Commissioners PP 1889 (HC No. 5685) 15-16.

${ }^{78}$ Report from the Select Committee on Charitable Trusts Acts PP 1884 (HC No. 306) xi; Report from the Select Committee on Charity Commission PP 1894 (HC No. 221).

${ }^{79}$ Report from the Select Committee on Charitable Trusts Acts PP 1884 (HC No. 306) 108-111 (QQ 1516-72, John Moxon Clabon). Some of the Commissioners' opinions on cases referred to the Attorney-General between 1872 and 1895 are in the National Archives: PRO/CHAR 16. 
many were lost through inertia or opposition by vested interests. Few schemes were enacted, ${ }^{80}$ and after a series of failures, the Commissioners gave up submitting contentious schemes to Parliament as a waste of money, time and effort. ${ }^{81}$

\section{The Charitable Trusts Act 1860}

The law was changed by the Charitable Trusts Act 1860, which empowered the Charity Commissioners to make orders 'such as may now be made by any judge of the Court of Chancery sitting at Chambers', including orders to establish schemes for the cy-près application of charity funds. ${ }^{82}$ Where it was doubtful whether the cy-près doctrine applied, the Commissioners would refer the matter to the Attorney-General. ${ }^{83}$ In other cases, they proceeded as a court would have done when asked to make a cy-près order. They were bound by court decisions when deciding if a cy-près event had occurred, and how to apply the trust property if it had, and although they were not bound to follow their own previous decisions, they accumulated a body of in-house precedents which they tried to follow in the interests of consistency. ${ }^{84}$

The Charity Commissioners could impose a scheme on trustees who refused to cooperate only where the annual trust income was $£ 50$ or less. When dealing with larger trusts, they could act only with the consent of a majority of the trustees, although once a majority had formally applied for a scheme, the Commissioners had jurisdiction over the charity property and the trustees could not change their minds and withdraw their application, e.g. because the Commissioners made a scheme they disliked. ${ }^{85}$ Trustees could, however, appeal the Commissioners' orders to the Chancery Court. ${ }^{86}$

The small size of their staff meant that it was never feasible for the Charity Commissioners to seek out endowments whose purposes had become obsolete: they had to wait for these to be brought to their notice. ${ }^{87}$ Nonetheless, the 1860 Act wrought a significant change. Most charities in England and Wales had an income of less than

\footnotetext{
${ }^{80}$ In the 16 years between 1853 and 1869 , only 18 bills were passed: Hansard, 3rd series, vol. 194, col. 1370 (WE Forster) (15 March 1869).

${ }^{81}$ Sixth Report of the Charity Commissioners for England and Wales PP 1859 (HC No. 2484) 5; Sixteenth Report of the Charity Commissioners for England and Wales PP 1868-69 (HC No. 4117) 4-6; Report from the Select Committee on Charitable Trusts Acts PP 1884 (HC No. 306) 11-12 (QQ 149-150 and 155, Henry Longley) and 184 (Q 2880, Sir Arthur Hobhouse).

${ }^{82}$ Charitable Trusts Act 1860 (23 \& 24 Vict., c. 136), s. 2.

${ }^{83}$ Report from the Select Committee on Charitable Trusts Acts PP 1884 (HC No. 306) 12-13 (QQ 157 and 163, Henry Longley).

${ }^{84}$ Report from the Select Committee on Charity Commission PP 1894 (HC No. 221) 7 (QQ 87-91, Sir Henry Longley), 281-282 and 288 (QQ 3955-6 and 4029, Lord Justice Davey).

${ }^{85}$ Re Poor's Land Charity, Bethnal Green [1891] 3 Ch. 400.

${ }^{86}$ Under section 8 of the 1860 Act, later amended by the Charitable Trusts Act 1869, section 10, which required the Attorney-General's consent before any such appeal could go ahead.

${ }^{87}$ Report from the Select Committee on Charitable Trusts Acts PP 1884 (HC No. 306) 15 (Q 188, Henry Longley) and 175 (Q 2739, Sir Arthur Hobhouse); Report from the Select Committee on Charity Commission PP 1894 (HC No. 221) 22 (Q 316, Sir Henry Longley).
} 
$£ 50,{ }^{88}$ and the effect of the statute was to transfer almost all non-contentious small charity work from the courts to the Commissioners. Between 1856 and 1860, the courts heard 1,279 applications for the appointment of trustees or establishment of schemes authorized by the Commissioners. Between 1861 and 1877, they heard 112, while the Commissioners made 5,820 orders of this kind. ${ }^{89}$ These included orders appointing new trustees as well as orders applying property cy-près, but by the early 1880 s the Commissioners had made around 4,000 cy-près schemes, mostly for charities with incomes under $£ 50$ and mostly with the trustees' consent. ${ }^{90}$

\section{The Endowed Schools Act 1869}

Endowed schools were financed out of endowed funds held on trust. By the 1860s there were around 3,000 endowed schools, only 800 of which provided education beyond the elementary level, and only 13 of which provided secondary education to girls. Few schools sent boys to the universities, and most had an annual income of less than $£ 100$. Many (though not all) of the schools' endowments fell within the cy-près jurisdiction of the courts and the Charity Commissioners, so that their funds could be redirected to other educational purposes if they had become defunct, e.g. through a lack of pupils. However, cases where a school's funds were merely mismanaged or applied ineffectively could not be dealt with in this way.

In 1868 the Schools Inquiry Commission chaired by Lord Taunton reported that the national provision of secondary education was inadequate and recommended a wholesale reorganisation of the funds held by endowed schools. It considered that the courts and the Charity Commissioners were unsuitable bodies to undertake this task and recommended the creation of a new body with sweeping powers to alter the governance arrangements of endowed schools, merge institutions, move schools from one locality to another, and so on. ${ }^{91}$ This led to the enactment of the Endowed Schools Act $1869,{ }^{92}$ which created the new Endowed Schools Commissioners and gave them powers to reorganize school endowments under section 9 that went beyond the cy-près principle, although they could only apply the funds to educational purposes. Under section 30 they were also empowered to apply to the purposes of education money that was held on charitable trusts for certain non-educational purposes that were no longer thought desirable, namely 'doles in money or kind; marriage portions; redemption of prisoners and captives; relief of poor prisoners for debt; loans; apprenticeship fees; [and] advancement in life'; also, money held on trust for 'purposes which have failed altogether or have become insignificant in comparison with the magnitude of the endowment.' The latter power could only be exercised with the trustees' consent. Schemes had to be approved by the Education Department and could be appealed to the Privy Council.

\footnotetext{
${ }^{88}$ In 1884 there were around 40,000 charities, 90\% of which had an annual income of less than £50: Report from the Select Committee on Charitable Trusts Acts PP 1884 (HC No. 306) 14 (QQ 182, 185-6 and 189-190, Henry Longley).

${ }^{89}$ Twenty-fifth Report of the Charity Commissioners for England and Wales PP 1878 (HC No. 2061) 5-7.

${ }^{90}$ Report from the Select Committee on Charitable Trusts Acts PP 1884 (HC No. 306) vi.

${ }^{91}$ Report of the Schools Inquiry Commission PP 1867-68 (HC No. 3966) vol. 1, 469471.

$9232 \& 33$ Vict., c. 56.
} 
The Endowed Schools Commissioners had a short but stormy history, and their progress in making schemes for endowed schools was slow: after three years only 24 schemes had passed into law. ${ }^{93}$ The tenacity with which many trustees fought to retain their existing arrangements played a part in this. So did the outspokenness of two Endowed Schools Commissioners: even before they had begun in office, Lord Lyttleton and Arthur Hobhouse had publicly committed themselves to radical reform and the robust treatment of entrenched interests. ${ }^{94}$ After five years of argument, and a change of government, the Endowed Schools Commissioners' powers were transferred to the Charity Commissioners by the Endowed Schools Act $1874 .^{95}$

For the next decade, the Charity Commissioners concentrated their efforts on unopposed schemes and steered clear of controversy. 500 schemes were passed. However, the Charity Commissioners were also criticised, for supporting the Anglican control of schools (which upset the Nonconformists), ${ }^{96}$ for failing to appropriate funds to support elementary schools (which the Charity Commissioners argued should be funded by ratepayers) and for using 'free school' endowments and dole funds to create fee-charging schools (which followed the Taunton Commissioners' guidelines, but which favoured well-off children over poor children, to whom few scholarships were awarded, where these even existed). ${ }^{97}$ The Charity Commissioners' jurisdiction over endowed schools was transferred to the Board of Education in $1900 .^{98}$

\section{The City of London Parochial Charities Act 1883}

By the late 1800s, many poor inhabitants of the City of London had been driven out by rising rents and had moved to cheaper dwellings in the East End. Hence, while the rise in rents meant that parochial charities which owned land in the area had more money, it also meant that many fewer people lived in the parishes who needed their assistance. The Charity Commissioners reported on several occasions that the resulting anomalies were too widespread to be cured by the piecemeal making of cy-près schemes, ${ }^{99}$ and a Royal Commission was eventually appointed, which agreed that a more systematic approach was needed. ${ }^{100}$ The result was the City of London Parochial Charities Act 1883. ${ }^{101}$ This empowered the Charity Commissioners to reorganize parochial charities in the City of London and to apply their funds over a wider geographical area and to

\footnotetext{
${ }^{93}$ Report of the Endowed Schools Commissioners PP 1872 (HC No. 524) 12.

${ }^{94}$ Owen, English Philanthropy, 255.

9537 \& 38 Vict., c. 87.

${ }^{96}$ See $\mathrm{n} .125$ and accompanying text.

${ }^{97}$ For their practice, see Report from the Select Committee on Charity Commission PP 1894 (HC No. 221) 80 (QQ 1242-4, Douglas Richmond); and for criticism, see ibid, 255, 260-1 and 262-3 (QQ 3709-10, 3763, 3767, and 3785-3800, Jesse Collings MP).

${ }^{98}$ By an order in council under the Board of Education Act 1899 (62 and 63 Vict., c. 33), s 2. See P.H.J.H. Gosden, 'The Board of Education Act, 1899' 11 British Journal of Educational Studies (1962), 44.

${ }^{99}$ Thirteenth Report of the Charity Commissioners for England and Wales PP 1866 (HC No. 100) 3-4; Twenty-fourth Report of the Charity Commissioners for England and Wales PP 1877 (HC No. 1705) 5-6; Twenty-eighth Report of the Charity Commissioners for England and Wales PP 1881 (HC No. 2862) 12.

${ }^{100}$ Report of the Royal City Parochial Charities Commission PP 1880 (HC No. 2522). 10146 \& 47 Vict., c. 36.
} 
new purposes which the Commissioners believed to be a better use of the money. ${ }^{102}$ These included the provision of schools, polytechnics, ${ }^{103}$ hospitals and libraries; $;{ }^{104}$ tracts of land on the edges of London's ever-expanding suburbs were also bought to be maintained as open spaces. ${ }^{105}$

The Commissioners' powers under the 1883 Act were not subject to the limits of the cy-près doctrine, save with respect to endowments held on ecclesiastical trusts, which could be pooled so as to apply the money to the needs of the whole capital, but the purposes of which could not otherwise be changed. ${ }^{106}$ The five largest parishes were left to handle their own charities in accordance with schemes framed by the Charity Commissioners, but the trustees of the remaining one hundred charities were relieved of their duties and management of their funds was placed in the hands of a new board, the Trustees of the London Parochial Charities. Before this could be done, however, much preliminary legal and administrative work was needed, and two additional Commissioners were appointed to handle this: Sir Francis Sandon, formerly Permanent Secretary of the Education Office, and James Anstie QC, a barrister. Even so, the work took nearly ten years.

\section{Case Studies}

A detailed investigation of all the cy-près orders and schemes made in the Victorian period is beyond the scope of this article, but some illustrative cases are examined here. These fall within one of the four categories of charitable purpose identified by Samuel Romilly in his argument as counsel in Morice v Bishop of Durham, and later adopted in Commissioner for Special Purposes of Income Tax v Pemsel. ${ }^{107}$

\section{Advancement of Learning: Attorney-General v Cullum (1842)}

Many orders and schemes were made by the courts and Charity Commissioners to fund schools, not only with property that had always been held for educational purposes, but also with property that had been settled for relief of the poor, or for the benefit of those living in a particular town or locality. The reallocation of money that had been settled for purposes of the latter kind reflected an 'official' view that self-improvement was a better answer to the problem of poverty than gifts of money or necessaries - a point to which we shall return. ${ }^{108}$ Some contentious issues that arose in connection with cy-près

${ }^{102}$ Materials relating to the Commissioners' administration of the 1883 Act are in the National Archives: PRO/CHAR 14.

103 e.g. Thirty-fifth Report of the Charity Commissioners for England and Wales PP 1888 (HC No. 5347) 16-17; Thirty-sixth Report of the Charity Commissioners PP 1889 (HC No. 5685) 36-47.

104 e.g. Thirty-sixth Report of the Charity Commissioners PP 1889 (HC No. 5685) 5052.

105 e.g. Thirty-fifth Report of the Charity Commissioners for England and Wales PP 1888 (HC No. 5347) 15-16.

106 There were similar problems in e.g. Bristol, Exeter, and Norwich, but although they wanted them, the Commissioners were never granted powers to consolidate the parochial charities in these cities: Report from the Select Committee on Charitable Trusts Acts PP 1884 (HC No. 306) 76 (QQ 966-7, Henry Longley).

${ }^{107}$ See text to nn. 22-24.

${ }^{108}$ See text to nn. 147-151. 
schemes to fund schools concerned religious instruction: should this be provided; should it be non-denominational or should the children be taught the doctrines of the Church of England and required to attend Church services; and should the children of parents who adhered to other religious creeds - Nonconformists, Roman Catholics and Jews - be allowed to opt out?

The answers given to these questions by the courts and Charity Commissioners and the aggrieved reactions of Nonconformists, formed part of a broader set of religious controversies in the $1700 \mathrm{~s}$ and $1800 \mathrm{~s}$, the main driver of which was the spectacular growth of Nonconformism between 1750 and $1850,{ }^{109}$ and extension of the franchise to constituencies in industrial towns where Dissent was strong. Nonconformist pressure for religious, civic and political equality resulted, among other things, in the removal of religious barriers to entry into public office ${ }^{110}$ and the abolition of church rates. ${ }^{111}$ These measures were very contentious and so were the legal rules affecting education. By the start of Victoria's reign, Nonconformists had been allowed to run their own schools for a century, ${ }^{112}$ and the University of London had been founded (in 1826) to provide a secular university education. But Dissenters were excluded from Oxford and Cambridge Universities until the $1850 \mathrm{~s},{ }^{113}$ and the terms on which their children were admitted into other schools, and the fact that these were controlled by the Anglican Church, even when they were funded with supposedly non-denominational 'public' money, were continuing sources of grievance.

Attorney-General v Cullum ${ }^{114}$ concerned a charity founded in the mid-1400s for the benefit of the inhabitants of Bury St Edmunds. By 1810, the trust property was being carelessly mismanaged, and an order was made appointing new trustees, ${ }^{115}$ but in 1836 an information was filed with the Attorney-General by the town inhabitants, alleging further mismanagement. Langdale MR directed the Chancery Master to take an account and make a scheme for its future management and application of the income,

${ }^{109}$ By the 1840 s, about $10 \%$ of the population and $20 \%$ of the electorate were Nonconformists: M.R. Watts, The Dissenters, vol. 2: The Expansion of Evangelical Nonconformity, Oxford, 1995, 23.

${ }^{110}$ Sacramental Test Act 1828 (9 Geo. IV, c. 17); Roman Catholic Relief Act 1829 (10 Geo. IV, c. 7); Parliamentary Elections Act 1835 (5 \& 6 Will. IV, c. 36); Declarations by Quakers Act 1838 ( 1 \& 23 Vict., c. 5); Municipal Offices Act 1845 (8 \& 9 Vict., c. 52); Religious Disabilities Act 1846 (9 \& 10 Vict., c. 59); Oaths of Allegiance and Relief of Jews Act 1858 (21 \& 22 Vict., c. 48); Parliamentary Oaths Act 1866 (29 \& 30 Vict., c. 19).

${ }^{111}$ Compulsory Church Rate Abolition Act 1868 (31 \& 32 Vict., c. 109).

112 The last attempt to prosecute a Dissenter for teaching without a licence seems to have been in 1733: D.L. Wykes, 'The Contribution of the Dissenting Academy to the Emergence of Rational Dissent', in K Haakonssen, ed., Enlightenment and Religion: Rational Dissent in Eighteenth-Century Britain, Cambridge, 1996, 99, 102. Dissenters were allowed to teach without a license by the Nonconformist Relief Act 1779 (19 Geo. III, c. 44).

${ }^{113}$ Oxford University Act 1854 (17 \& 18 Vict., c. 71); Cambridge University Act 1856 (19\& 20 Vict., c. 88$)$.

114 (1842) 1 Y. \& C. 411, 62 ER 948.

115 The Roman Catholic Relief Act 1791 (31 Geo. III, c. 32) abolished penalties for public adherence to Catholicism, but trusts for the furtherance of Catholicism continued to be illegal per se: Cary v Abbot (1802) 7 Ves. Jun. 490, 32 ER 198. 
which by then amounted to $£ 2,110$ per annum. ${ }^{116}$ The Master made a scheme which included the foundation of three schools, which would be open to the children of parents of all religious denominations. He proposed that the schools should close on Sundays, that part of the school hours should be set apart for reading Scripture lessons, but that no other religious instruction should be provided.

The trustees objected and brought proceedings to obtain a judicial declaration that religious instruction in the schools should be given a more prominent place in the curriculum and a more pronounced Anglican content. Knight-Bruce V-C held that 'any scheme of education without religion would be worse than a mockery', that he 'did not ... question the equal right of every Roman Catholic and every Protestant Dissenter in the town of Bury to a participation of all the advantages of the charity', but that 'religious instruction could not be provided for every class of persons holding different religious opinions', and that 'if education, of course including religious instruction, is to be provided for, ... it must be according to the doctrines and principles of the English Church. ${ }^{117} \mathrm{He}$ ordered the Master to reconsider whether the scheme should include the provision of education in the town, and if so, to provide 'that there is to be no master, mistress or teacher, who is not a member of the Church of England, and that no other course of religious instruction shall be adopted than in conformity with that Church., ${ }^{118}$

The parties then agreed a scheme, confirmed by the Vice-Chancellor, under which the teachers would be members of the Church of England; an hour of religious instruction would be given every day to all the children, being confined to the reading and explanation of the Scriptures; instruction would be given every Sunday in the liturgy, catechism and articles of the Church of England to those children whose parents were Anglicans; and every child should be required to attend Church services twice every Sunday, subject to the proviso that the trustees might excuse any child of parents who were not Anglicans.

These details are significant because this scheme formed the template for many other schemes that were subsequently made to apply charitable funds to the provision of schooling. ${ }^{119}$ In 1868, the Charity Commissioners stated that Cullum was 'a sound and binding decision ... [and] constantly followed without argument', ${ }^{120}$ although they took another approach where a trust's founding document required the teaching of a particular religious dogma, as no conscience clause could then be inserted because this would be inconsistent with the founder's intentions. ${ }^{121}$ These rules were also written into the Endowed Schools Act 1869, which allowed parents to claim exemption for scholars from religious instruction and attendance at religious services, unless religious

\footnotetext{
${ }^{116}$ Att.-Gen. v Cullum (1836) 1 Keen 104, 48 ER 246.

${ }^{117}$ Att.-Gen. v Cullum (1842) 1 Y. \& C. 411, 415-416; 62 ER 948, 950.

118 Ibid, 416; 951.

119 e.g. Att.-Gen. v Haberdashers' Company (1854) 19 Beav. 385, 52 ER 399; Att.-Gen. $v$ Clifton (1863) 32 Beav. 596, 600; 55 ER 234, 236; Sixteenth Report of the Charity Commissioners for England and Wales PP 1868-69 (HC No. 4117) 20-32.

${ }^{120}$ Sixteenth Report of the Charity Commissioners for England and Wales PP 1868-69 (HC No. 4117) 22.

${ }^{121}$ Att.-Gen. v Calvert (1857) 23 Beav. 248, 255-257; 53 ER 97, 100-101; Att.-Gen. v Market-Bosworth School (1865) 35 Beav. 305, 55 ER 913. See too Seventeenth Report of the Charity Commissioners PP 1870 (HC No. 73) 28 (scheme for the Kelly College, clause 40).
} 
instruction and church attendance were required by the terms of the original endowment and these terms had been observed ever since. ${ }^{122}$

Even where they were protected by a conscience clause, Nonconformist and Roman Catholic parents came under pressure from Anglican teachers to allow their children to receive instruction in Anglican doctrine - and the Church of England kept a firm grip on teaching appointments for the rest of the century. When making schemes that included the appointment of new trustees, the usual practice of the courts and the Commissioners was to appoint vicars and churchwardens as trustees, who would in turn appoint Anglican teachers, even in areas where most of the local population for whose benefit a trust had originally been established had become Dissenters. ${ }^{123}$ This may have been defensible on the grounds of adherence to the settlor's original intentions in cases where the provision of Anglican religious instruction was required by the trust deed. ${ }^{124}$ However, the same claim could not be made of cases where the original trust purposes were non-denominational. The Commissioners argued that vicars and churchwardens were usually the only people in a parish with the social status, education and time needed to run the trusts effectively. However, this was denied by Nonconformists, whose growing wealth, social respectability and educational attainments made the argument seem ever less convincing as time passed. ${ }^{125}$

\section{Advancement of Religion: Attorney-General v St Cross Hospital (1853)}

According to the Brougham Commissioners, writing in 1838,

The institutions in which the directions of the founder are most obviously unsuited to the present times, are various hospitals established originally for keeping up certain religious or superstitious observances. ${ }^{126}$

Hospitals were religious foundations first introduced in the eleventh century. Religious worship was an essential part of their function, but they also provided housing and care to the sick and debilitated, lepers, and the morbidly diseased, housing to pilgrims and travellers, and doles to the poor. ${ }^{127}$ By the nineteenth century, many hospitals had

${ }^{122}$ See the explanation of these sections given in Report from the Select Committee on Charity Commission PP 1894 (HC No. 221) 83-4 (QQ 1287-1301, Douglas Richmond). 123 e.g. Sixteenth Report of the Charity Commissioners for England and Wales PP 186869 (HC No. 4117) 20-32.

${ }^{124}$ As in e.g. Re Ilminster Free School (1858) 2 De G. \& J. 535, 44 ER 1097.

${ }^{125}$ For allegations and denials of the Commissioners' bias against Nonconformists, see 'Vigilans', Nonconformists and their Rights as Citizens: Especially in Relation to the Endowed Schools Act, London, 1873; Report from the Select Committee on Charitable Trusts Acts PP 1884 (HC No. 306) 161-3 (QQ 2498-2535, Rev Dr Henry Crosskey), 190 (QQ 2923-6, Sir Arthur Hobhouse), 194-206 (QQ 2960-3212, Rev Dr Henry Crosskey) and 281-2 (QQ 4536-58, Henry Longley); Report from the Select Committee on Charity Commission PP 1894 (HC No. 221) 25-26 (QQ 361-2, Sir Henry Longley). ${ }^{126}$ Thirty-Second Report of the Commissioners of Inquiry into Charities in England and Wales PP 1837-38 (HC No. 108) 5.

${ }^{127}$ N. Orme and M. Webster, The English Hospital, 1070-1570, New Haven, CT, 1995; S. Sweetinburgh, The Role of the Hospital in Medieval England: Gift-Giving and the Spiritual Economy, Dublin, 2004; S. Watson, 'The Origins of the English Hospital' 16 Transactions of the Royal Historical Society (6th series) (2006), 75. 
become ecclesiastical sinecures that generated incomes for their masters or wardens (and sometimes for their brethren), from whom little was expected in return. In many cases, their finances were badly mismanaged, and it had become a widespread practice for the master to lease a hospital's properties on fines, i.e. to take an upfront payment in exchange for granting a long lease of the properties at a fraction of their true worth.

Reform of these arrangements was a significant part of the charity work done by the Attorney-General and the Charity Commissioners in the mid-1800s. Their orders and schemes were part of a wider reform process led by the Ecclesiastical Commissioners, to eliminate pluralism, nepotism, sinecures, and clerical absenteeism from the parishes, ${ }^{128}$ and to reduce the disparity in income between the richest and poorest Anglican clergy. ${ }^{129}$ Hospitals targeted by reformers included the Hospital of Archbishop Holgate in York, where the twenty brothers and sisters were each paid $£ 94$ a year by 1850, an income which the Brougham Commissioners thought 'unnecessarily and mischievously large for persons in that station of life'. ${ }^{130}$ By the same date, the Magdalen Hospital in Newcastle-upon-Tyne, first established for the care of lepers, had evolved into an institution for the relief of poor brethren, and its annual revenue was $£ 1,500, £ 700$ of which went to the master and $£ 267$ to each of three brethren. ${ }^{131}$ The income of the master of Christ's Hospital, at Sherburn, near Durham, also far exceeded the costs of the hospital. He spent the surplus on other charitable purposes, but this expenditure entailed a breach of trust, and so in 1854 the Commissioners sought the enactment of a legislative scheme that included the establishment of a new institution for the relief of chronic diseases, by way of analogy to the trust's first purpose of the relief of persons afflicted with leprosy. This failed to pass through the House of Lords owing to the opposition of the bishops, rallied by the Bishop of Durham, who viewed the proposals as an attack on clerical control over the hospital's endowment. However, a scheme for the allocation of the surplus was eventually agreed following proceedings by the Attorney-General in $1857 .{ }^{132}$

The best-known hospital scandal concerned St Cross Hospital, near Winchester. This was widely reported in the press, ${ }^{133}$ and the story remains familiar because it was

${ }^{128}$ Measures to address these problems included the Pluralities Act 1838 (1 \& 2 Vict., c. 106) and the Ecclesiastical Commissioners' Act 1840 (3 \& 4 Vict., c. 113).

${ }^{129}$ K.A. Thompson, Bureaucracy and Church Reform: The Organisational Response of the Church of England to Social Change 1800-1965, Oxford, 1960; G.F.A. Best, Temporal Pillars: Queen Anne's Bounty, the Ecclesiastical Commissioners, and the Church of England, Cambridge, 1964.

${ }^{130}$ Second Report of the Royal Commission for Inquiring into Those Cases Which Were Investigated by, and Reported upon, by the Charity Commissioner, but not certified to the Attorney-General PP 1851 (HC No. 1371) 5-6.

${ }^{131}$ Fifth Report of the Charity Commissioners for England and Wales PP 1858 (HC No. 2346) 27.

132 Supplemental Report of the Charity Commissioners for England and Wales PP 1854-55 (HC No. 1966) 4-18; Copies of All Correspondence between the Bishop of Durham and the Charity Commissioners Concerning the Scheme for Sherburn Hospital PP 1856 (HC No. 134); Third Report of the Charity Commissioners for England and Wales PP 1856 (HC No. 2060) 13-28; Fourth Report of the Charity Commissioners for England and Wales PP 1857 (HC No. 2187) 5-6.

133 The case and its aftermath were reported at length in The Times, accompanied by thunderous editorializing ('shameless perversion of one of our noblest charities', 
an inspiration for Anthony Trollope's famous novel, The Warden, published in 1855. St Cross Hospital was a medieval foundation endowed for the maintenance of poor and impotent men under the government of a master who was appointed by the Bishop of Winchester. ${ }^{134}$ In 1808, Bishop North, whose own career had been advanced by his brother, the Prime Minister Lord North, awarded the mastership to his son, the Reverend Francis North, who was the sixth Earl of Guilford. Even by the standards of his age, Bishop North was remarkable for the success with which he 'extracted maximum familial advantage from his long episcopate': ${ }^{135}$ more than thirty livings and preferments in his gift went to members of his family. He had previously presented Guilford to the livings of Alresford and St Mary's, Southampton, benefices from which Guilford derived an income of $£ 3,500$ a year, and which he did not resign until 1850 (when he sought unsuccessfully to deflect criticism of his Mastership of St Cross by giving up his livings). North also made Guilford a prebendary of Winchester, adding another $£ 1,000$ to his income; Guilford resigned this post in 1827 when he succeeded to the Earldom and estates that brought in $£ 18,000$ a year.

The hospital's endowment should have generated an annual income of around $£ 9,000$ from the appropriation of tithes of various Hampshire parishes, many of which were perpetual curacies with small stipends paid to their incumbents. Following the practice of previous masters, however, Guilford leased out the tithes for a period of three lives at a reduced rent, on the payment of fines by the lessees. $2 \mathrm{~d}$ in the pound went to each brother, $6 \mathrm{~d}$ to the hospital chaplain, and the rest to Guilford. It is hard to form a clear picture of his average yearly income from the mastership, but it was probably in the region of $£ 2,000-£ 3,000 .{ }^{136}$

In 1843, Guilford attracted hostile newspaper comment when he was paid a fine of $£ 13,000$ for a long lease on the tithes of Crondal and other parishes that were collectively worth up to $£ 2,000$ a year; $£ 10,000$ of this payment he kept for himself. ${ }^{137}$ After this, the amount and sources of his income as master of the hospital were regularly criticized in the newspapers, and by 1849, the management of the hospital's finances had become a matter of such notoriety that a Radical MP, Joseph Hume, successfully sponsored a Parliamentary resolution for an inquiry. This led the Attorney-General to file a Chancery bill against Guilford for maladministration of the hospital's funds, seeking an order for its future regulation and management. The case was heard by Romilly MR in $1853 .{ }^{138}$ The Bishop of Winchester intervened to argue that the court had no jurisdiction to interfere with the hospital's affairs because these fell within the Bishop's own visitorial jurisdiction. However, the judge rejected this and directed that a scheme be made for the future administration of the charities, although he declined to order an account against Guilford for money received before the start of proceedings, as the Attorney-General had not asked for this in the information.

\footnotetext{
'unscrupulous cupidity', 'contempt for common decency'). See generally R.B. Martin, Enter Rumour: Four Early Victorian Scandals, London, 1962, 137-184.

${ }^{134}$ Thirty-first Report of the Commissioners of Inquiry into Charities in England and Wales PP 1837-8 (HC No. 103) 843-859; L.M. Humbert, Memorials of the Hospital of St Cross and the Almshouse of Noble Poverty, London, 1868, 14-52.

135 N. Aston, 'North, Brownlow (1741-1820)', Oxford Dictionary of National Biography; online edn, Jan 2008; http://www.oxforddnb.com/view/article/20292.

${ }^{136}$ Martin, Enter Rumour, 160; Humbert, Memorials of St Cross, 83-84.

${ }^{137}$ The Globe, 21 October 1843, cited in Martin, Enter Rumour, 166.

${ }^{138}$ Att.-Gen. v St Cross Hospital (1853) 17 Beav. 435, 51 ER 1103.
} 
A scheme for the management of the hospital was agreed and approved by the court in June $1855 .{ }^{139}$ Of particular note are provisions which took the management and control of the hospital's property out of the master's hands and placed them in the hands of trustees. It was also stipulated that the property should

from time to time be let and demised at the best annual rent or rents that can be obtained for the same ... without taking any fine, or premium, on the making of any such demise.

The same provision can be found in many schemes made by the Charity Commissioners in subsequent cases where hospital and other charity trustees had adopted the practice of leasing on fines to the detriment of the trust income. ${ }^{140}$ The scheme for St Cross Hospital also provided that the hospital should continue to house and feed the brethren, who should be poor men above the age of fifty, not in receipt of parish relief - this was also a standard provision in schemes for the relief of poverty. ${ }^{141}$ The master was henceforth to receive a salary of $£ 250$, and to perform Sunday services in the chapel.

\section{Relief of the Indigent: Re Campden Charities (1881)}

This case has already been mentioned. ${ }^{142}$ It concerned two testamentary trusts, the first settled by Viscount Campden in 1629, the second by his widow in 1643 . He left $£ 200$ 'to be yearly employed for the good and benefit of the poor of the town of Kensington for ever'; this money was used to buy a nearby estate. She left $£ 200$ on trust to buy land with an annual value of $£ 10$, half of which should be paid at half-yearly intervals to 'the most poor and needy people that be of good life and conversation' in Kensington, and the other half should be applied yearly to put poor boys of the parish to be apprenticed. Her legacy was used to buy land in Kensington and a third estate in the area was also bought in 1651. In 1757 all three estates were vested in trustees for the same purposes. Time passed and Kensington became a thickly populated suburb of London, with many middle-class residents. By 1879, the annual rental income on the charity land had risen to about $£ 3,600$, and the Charity Commissioners agreed a scheme with the trustees which closely followed the standard format devised by the Commissioners for the many dole charities whose funds they applied cy-près at that time. ${ }^{143}$

This provided that after the apprentice fees mentioned in the trust deed had been paid, the trustees should use no more than half of the remaining income for various purposes including the relief of poor accident victims and the provision of healthcare to the parish poor, and the payment of pensions to deserving poor parishioners of long standing. The rest was to be used for the education of children in the parish, in various ways, including the purchase of apprenticeships and the payment of money to parents to encourage them to keep their children in elementary school after the age of 11 by

\footnotetext{
${ }^{139}$ Details of the scheme can be found in Humbert, Memorials of St Cross, 82-84.

${ }^{140}$ Compare clause 5 of the Commissioners' proposed scheme for Sherburn Hospital, reproduced in Supplemental Report of the Charity Commissioners for England and Wales PP 1854-55 (HC No. 1966) 9-10.

${ }^{141}$ For the reasons explained below in the text following n. 147.

${ }^{142}$ See the text following n. 57.

${ }^{143}$ Report of Select Committee on the Charitable Trusts Acts PP 1884 (HC No. 306) 19-26 (QQ 253-347, Henry Longley).
} 
compensating them for the lost wages that their children would otherwise have earned from employment.

Some parishioners objected to this scheme, because it diverted a large portion of the trust income to educational purposes when there was no lack of deserving poor people in the parish to whom the money could be paid. They petitioned for an order that the scheme should be altered and the old mode of applying the trust income restored. Hall V-C found for the parishioners and ordered the Commissioners to reframe the scheme. He held that part of the income of Viscount Campden's charity could be applied to education, as he had not specified the mode in which poverty should be relieved under his trust. But Viscountess Campden had done so, and as it was still possible to buy apprenticeships, half of the income of her trust should be used for this, while the other half should be used to buy pensions.

The Court of Appeal disagreed. The lead judgment was given by Jessel MR, who held that an annual expenditure of $£ 1,100$ on buying apprenticeships went far beyond anything that Viscountess Campden could have contemplated. Moreover, it was no longer the case, as it had been in her lifetime, that those exercising a trade should have served an apprenticeship. Apprenticeships were becoming obsolete. Some masters still took apprentices, and some boys still wished to serve them, and so some money could still be spent on this purpose. However, this was a case where

the means to an end require[d] change, the end being kept in view; the end to be kept in view being such an education to be given the young poor of the parish as [would] enable them to gain their livelihood in an honest and respectable manner. ${ }^{144}$

Hence the cy-près application of the bulk of the apprenticeship funds to more general educational purposes was appropriate.

So, too, was the cy-près application of the dole money. Doles 'tend[ed] to demoralize the poor and benefit no one' and 'the extension of doles [was] simply the extension of mischief.' ${ }^{145}$ Viscountess Campden had wanted 50 shillings a year to be distributed in sums that would make a difference to a few poor villagers, selected by churchwardens who knew them personally, not that 500 sovereigns should be handed out to the poor of a town every six months. The consequence of that would be 'a pauper population flocking into Kensington, merely attracted there by the existence of these charities, a thing which ha[d] happened in some parishes in England'. ${ }^{146}$ Indeed, the trustees had recognized this, since for many years they had paid pensions to a few chosen paupers, rather than distributing the fund in the small sums directed. It followed that the Commissioners' scheme should be upheld.

The scheme made in the Campden Charities case, and the terms of Jessel MR's judgment, were characteristic of contemporary 'official' attitudes towards the role of charity in relieving poverty. ${ }^{147}$ Charitable relief of the 'deserving' poor was desirable,

\footnotetext{
${ }^{144}$ Re Campden Charities (1881) 18 Ch D 310, 326.

145 Ibid. 327.

146 Ibid. 329.

${ }^{147}$ G. Himmelfarb, The Idea of Poverty: England in the Early Victorian Age, London, 1984; G. Himmelfarb, Poverty and Compassion: The Moral Imagination of the Late Victorians paperback edn, New York, NY, 1992; L.H. Lees, The Solidarities of Strangers: The English Poor Laws and the People, 1700-1948, Cambridge, 1998; W. Cornish et al, Law and Society in England 1750-1950, 2nd edn, Oxford, 2019, ch. 6.
} 
but relief of the 'undeserving' was a matter for the poor law: they would be provided for, but only in conditions that incentivized them to sell their labour rather than rely on parish relief. The distribution of doles, even to the deserving poor, was 'demoralizing' because it made the recipients over-reliant on handouts. This was why the authors of the 1834 Report on the Poor Law said that dole charities 'have a quality of evil peculiar to themselves'; ${ }^{148}$ and the same view was aired in many of the Charity Commissioners' reports ${ }^{149}$ and in court judgments. ${ }^{150}$ Yet the opponents of dole charities contradicted themselves: the distribution of small sums was denounced as pointless because it made no real difference to the recipients, and yet it was also said to attract poor scroungers into neighbourhoods where distributions were made. The latter claim was repeatedly asserted by Arthur Hobhouse amongst others, without offering any empirical evidence that dole payments had this effect. ${ }^{151}$

Nor did opinion regarding dole funds all go in one direction. The recipients of doles wished them to continue, for obvious reasons, and they protested if the money was withdrawn and applied to other purposes. ${ }^{152}$ The trustees of dole charities continued to pay doles despite the Charity Commissioners' complaints, ${ }^{153}$ testators continued to create new dole charities, ${ }^{154}$ and emergency appeals continued to raise large sums for direct temporary relief to the poor at times of mass unemployment. ${ }^{155}$ The fact was that many people believed the payment of doles to be a religious and social duty which reinforced and validated social bonds between rich and poor, and nothing which was said by the proponents of 'scientific charity' changed their opinion.

${ }^{148}$ Report from His Majesty's Commissioners for Inquiring into the Administration and Practical Operation of the Poor Laws PP 1834 (HC No. 44) 204. See too E. Chadwick, 'The New Poor Law' 63 Edinburgh Review (1836), 495-496.

${ }^{149}$ Fifth Report of the Charity Commissioners for England and Wales PP 1858 (HC No. 2346) 18; Sixteenth Report of the Charity Commissioners for England and Wales PP 1868-69 (HC No. 4117) 6; Fortieth Report of the Charity Commissioners for England and Wales PP 1893-4 (HC No. 6960) 17 ff.

${ }^{150}$ Att.-Gen. v Marchant (1866) LR 3 Eq. 424, 431; Re Stanes' Will (1853) 21 LT (OS) 261; Re Foveaux [1895] 2 Ch. 501, 505 (quoted above in the text to n. 29).

${ }^{151}$ M. Baker and M. Collins, 'The Governance of Charitable Trusts in the Nineteenth Century: The West Riding of Yorkshire' 27 Social History (2002), 162, 175-177. See also Sir A. Hobhouse, The Dead Hand, London, 1880, 38-41, 96-8, 195-215.

152 Report from the Select Committee on Charitable Trusts Acts PP 1884 (HC No. 306) 117 and 120 (QQ 1659-1660, 1667 and 1730, John Moxon Clabon) and 274 (QQ 40024003, Robert Leader); Report from the Select Committee on Charity Commission PP 1894 (HC No. 221) 255 (QQ 3706 and 3708, Jesse Collings MP).

${ }^{153}$ Report of Select Committee on Charitable Trusts Acts PP 1884 (HC No. 306) $\mathrm{x}$ and 28-30 (QQ 368-382 and 386-407, Henry Longley); Report from the Select Committee on Charity Commission PP 1894 (HC No. 221) 31 (Q 462, Sir Henry Longley).

${ }^{154}$ Twenty-third Report of the Charity Commissioners for England and Wales PP 1876 (HC No. 1455) 5; Report of Select Committee on Charitable Trusts Acts PP 1884 (HC No. 306) 24 (Q 321, Henry Longley).

155 Over $£ 1,275,000$ during the Lancashire Cotton Famine of 1861-1865: W.O. Henderson, The Lancashire Cotton Famine, 1861-1865, Manchester, 1934, ch. 4; $£ 80,000$ paid into the Mansion House Fund for the poor raised by the Lord Mayor of London in 1885-1886: R. Whelan, Helping the Poor: Friendly Visiting, Dole Charities and Dole Queues, London, 2001, 59-89. 
4. Advancement of Objects of General Public Utility / Reduction of Local Tax Liabilities and/or Performance of Local Government Duties: Attorney-General v Talbot (1892) and Attorney-General v Day (1900)

An associated issue was the use of charitable endowments to pay the poor rate. The Charity Commissioners objected to this, partly because charitable funds were meant to be spent on the deserving rather than the undeserving poor, and partly because it effectively reduced the poor rate that would otherwise have been payable by taxpayers in the area, with the result that it enured to the benefit of rich taxpayers rather than poor people in the locality. ${ }^{156}$ This objection was also made to other applications of charity property that reduced the tax burden on the rich. For example, once the Education Act 1870 had placed the burden of paying for elementary education onto local ratepayers, ${ }^{157}$ the Charity Commissioners said that trusts to provide poor children with an education should not be applied to the general maintenance of elementary schools, and should instead be used to pay individual children to stay at elementary schools for longer (rather than leaving school for paid employment) or to fund scholarships to support entry into secondary education. ${ }^{158}$ The significance of this general issue increased during the closing decades of the nineteenth century, when a greater burden was laid on local government bodies to provide civic infrastructure and other amenities for local residents and to pay for these out of local taxation. ${ }^{159}$

To understand this issue, one needs to know the history of borough corporations and their transformation into municipal corporations by legislation passed in 1835 . Many borough corporations had been created long before then and had been charged from their earliest years with the provision of infrastructure and amenities such as walls, roads, bridges, water supplies, and so on. Initially, it had been expected that these would be paid for out of local taxation, but over time, charities had been founded to pay for the provision of such benefits to the town inhabitants. In most towns, by the mid-1830s, the combined incomes of these charities had become much larger than the tax revenues taken by the corporation. For example, the combined incomes of the municipal charities of the principal West Riding towns were as follows: Sheffield $£ 6,000$; Leeds $£ 4,800$; Wakefield £3,000; Halifax £1,500; Doncaster £900; Ripon $£ 600$; Pontefract $£ 500$. With the exception of Doncaster Corporation (nearly £12,000), the corporations had much smaller incomes: for example, Leeds $£ 200$; Ripon $£ 150$; Pontefract $£ 160$. ${ }^{160}$

${ }^{156}$ Third Report of the Charity Commissioners for England and Wales PP 1856 (HC No. 2060) 8-9; Report from the Select Committee on Charitable Trusts Acts PP 1884 (HC No. 306) 180 (QQ 2819-2820, Sir Arthur Hobhouse). The use of charitable funds to reduce the poor rate was also suspended by the City of London Parochial Charities Act 1883, s. 41.

15733 \& 34 Vict., c. 75.

158 Report from the Select Committee on Charitable Trusts Acts PP 1884 (HC No. 306) 79-80 and 86-7 (QQ 1009, 1034, and 1127-1139, Henry Longley) and 233 (Q 3646, Douglas Richmond).

${ }^{159}$ See the text to nn. 12-16.

${ }^{160}$ K. Grady, 'The Records of the Charity Commissions: A Source for Urban History' 9 Urban History (1982) 31, 32, citing Analytical Digest of the Reports of the Commissioners of Inquiry into Charities PP 1843 (HC No. 433) 672-719 and First Report of the Commissioners Appointed to Inquire into the Municipal Corporations in England and Wales PP 1835 (HC No. 116) 1615-1624, 1671-1679,1705-1710 and 1491-1507. 
These figures reflect the fact that by the early $1800 \mathrm{~s}$, most towns were effectively run by the trustees of the municipal charities, rather than the borough councillors per se, although the trustees and the councillors were often the same people. These arrangements were brought to an end by the Municipal Corporations Act 1835 . This legislation is often characterised as a partisan Whig measure designed to break Tory control of the borough corporations, redistribute their patronage and reduce their influence on parliamentary elections. There is truth in this, but it is also true that many contemporaries believed the borough corporations to be unrepresentative oligarchies and that (among other bad practices) town officials abused their positions as charity trustees by using charity funds for their own benefit. ${ }^{161}$ To prevent this, sections 71-73 of the Act severed the administration of municipal charities from the jurisdiction of borough corporations, whose officers were compulsorily retired from the trusteeship of municipal charities and replaced by independent trustees. ${ }^{162}$

By the closing decades of the century, the reputation of borough corporations had recovered, and town councillors were keen to regain control of the municipal charities, or at least to acquire a say in the decisions taken by the charity trustees. This led to a series of battles with the Charity Commissioners and the courts, who slowly retreated from the position that a sharp distinction could and should be maintained between the publicly funded provision of certain types of benefit by local authorities and the provision of other types of benefit by charity trustees. For example, in the early 1880s the Commissioners would not allow Birmingham Corporation to nominate a majority of the trustees of Lench's Charity, which maintained 150 almshouses in the borough. ${ }^{163}$ Yet a decade later it had become the Commissioners' regular practice to appoint trustees nominated by borough corporations when making schemes to apply money for the benefit of town inhabitants. ${ }^{164}$

In Attorney-General v Talbot ${ }^{165}$ Chitty J refused to let Leeds Corporation take control of a trust for maintaining the highways of Leeds. Yet a few years afterwards, in Attorney-General $v$ Day, ${ }^{166}$ North J held that the income of a trust for the repair of a road should be paid to Cambridgeshire County Council and Chesterton District Council, because responsibility for maintaining the road had been imposed on these councils by the Local Government Act 1888. It was argued that once the councils had been made responsible for the repairs by statute, the trust funds were no longer needed for this purpose, and so the money should be applied elsewhere. However, the judge rejected this and held that

The fund is devoted to a charitable purpose, namely, the repair of the road, and it seems to me that the persons in whom the road is vested, and who are under

161 First Report of the Commissioners Appointed to Inquire into the Municipal Corporations in England and Wales PP 1835 (HC No. 116) 47-48. See too G.B.A.M. Finlayson, 'The Municipal Corporation Committee and Report, 1833-35' 36 Bulletin of the Institute of Historical Research (1963), 36; G.B.A.M. Finlayson, 'The Politics of Municipal Reform, 1835' 81 English Historical Review (1966), 673.

${ }^{162}$ Enforced in e.g. Re Norwich Charities (1837) 2 My. \& Cr. 275, 40 ER 645.

${ }^{163}$ Report from the Select Committee on Charitable Trusts Acts PP 1884 (HC No. 306) 96-97 and 126-132 (QQ 1332-1341 and 1808-1870, Henry Longley).

${ }^{164}$ Report from the Select Committee on Charity Commission PP 1894 (HC No. 221) 26-7 (QQ 375-384, Sir Henry Longley).

${ }^{165}$ The Times, 11 April 1892, 3E.

166 [1900] 1 Ch. 31. 
the liability to repair it, have the benefit of these trusts which have been created for providing the sums I have mentioned for that purpose. ${ }^{167}$

The inconsistent nature of these decisions can be attributed to several causes. First, it was impossible for the courts to accept that the repair of public highways was not a legally charitable purpose, given their commitment to the rule that purposes listed in the 1601 Preamble were legally charitable purposes, ${ }^{168}$ and given that these included 'the repair of bridges, havens, causeways, churches, sea banks and highways'. Secondly, they were also committed to the rule that once a purpose had been recognised as legally charitable, it could not be said that it had ceased to be so as a result of changing social circumstances. ${ }^{169}$ Thirdly, however, once the idea had taken hold that tax revenues should be used to fund the provision of some types of public benefit, it became tempting for the courts and the Charity Commissioners to divert charitable funds which were themselves held for this purpose into another purpose, there being no shortage of social problems to the cure of which the money might be applied. Fourthly, though, diverting the funds into different purposes would subvert the intentions of the settlor, contrary to the commitment which was felt by the courts and the Commissioners to respect these, not only because the settlor had been entitled as property owner to choose what should happen to the property, but also out of a fear that the well-springs of charity would dry up if intending settlors were left with the impression that their property might be taken and used for purposes which they had not chosen.

Little wonder, then, that the courts and the Commissioners were in a quandary, and little wonder that the general issue raised by these cases remains unresolved today, finding its modern expression in uncertainty over the legal requirement that charities must be independent of government. ${ }^{170}$ This rule is hard to reconcile with the fact that there is a substantial overlap between the activities undertaken by charities and the state and with the fact that the main sources of funding for many charities are grants made by government bodies and contracts entered with them.

\section{Conclusion}

This article has discussed measures taken during the Victorian period to redirect funds held on charitable trust from the original purposes of the trust into new purposes that were believed by the courts and the Charity Commissioners to be more socially useful. Their understanding of the rules which governed their ability to do this and the choices which they made about the cy-près application of funds have been examined. As might have been expected, their views about social policy reflected contemporary 'official' attitudes, and since these changed over time, so too did the opinions held by the courts and Commissioners about the way in which social problems should be conceived and the action needed to resolve them. As one might also have expected, their conception of these questions differs markedly from the way they are conceived today, for great changes took place during the twentieth century in attitudes and expectations regarding

\footnotetext{
${ }^{167}$ Ibid., 36.

${ }^{168}$ See the text to nn. 21-26.

${ }^{169}$ See the text to nn. 29-32.

${ }^{170}$ See IRC v Oldham Training and Enterprise Council [1996] STC 1218; Charity Commission, RR 7: The Independence of Charities from the State, October 2009; https://assets.publishing.service.gov.uk/government/uploads/system/uploads/attachme nt_data/file/358888/rr7text.pdf
} 
the state provision of welfare benefits funded from taxation and indeed the relations between state and citizen more generally. When making cy-près orders and schemes, however, the courts and the Charity Commissioners conceived themselves to be faced by one question which is conceived in the same terms by their descendants in office, and which was as hard to resolve in Victorian times as it is today: what to do when the law requires the perpetuation of property-owning arrangements which are premised on social assumptions and attitudes to which the generality of people no longer subscribe?

\section{Acknowledgements}

The opinions expressed in this article are my own and I am solely responsible for errors. With that caveat, I acknowledge the generous help that I have received from many people who commented on drafts: the anonymous referees, members of the London and Oxford Legal History Discussion Groups, Joshua Getzler, Michael Lobban, Charlotte Mitchell, Paul Mitchell, Debra Morris, Rachael Mulheron, Pauline Ridge, Chantal Stebbings and John Styles.

\section{Disclosure Statement}

No potential conflict of interest was reported by the author.

\section{Notes on Contributor}

Charles Mitchell QC (Hon) FBA is a Professor of Law at University College London. He is a co-author of Law and Society in England 1750-1950, 2nd edn, Oxford, 2019, with William Cornish, Stephen Banks, Paul Mitchell and Rebecca Probert. 